\title{
Legal Issues Related to COVID-19 Under International Law
}

\author{
Zhang Naigen \\ Law School, Fudan University, Shanghai, China
}

Email address:

zhangng@fudan.edu.cn

To cite this article:

Zhang Naigen. Legal Issues Related to COVID-19 Under International Law. International Journal of Science and Qualitative Analysis. Vol. 7, No. 1, 2021, pp. 21-29. doi: 10.11648/j.ijsqa.20210701.14

Received: May 17, 2021; Accepted: June 7, 2021; Published: June 22, 2021

\begin{abstract}
The COVID-19 pandemic is an event of public health of international concern with extraordinary negative impacts on international community. Some legal issues have been raised by someone who accused Chinese failing to cooperate with World Health Organization and other countries to prevent spread of coronavirus over the world. In fact, several cases have been filed in the federal courts of the United States. This situation makes necessary for legal response. Against theses backgrounds, this paper argues the merits to respond such accusations in accordance with the international laws, focusing on three legal issues, first, to distinguish the general obligations of international cooperation for global health under Constitution of World Health Organization from the special obligations in fighting COVID-19 according to International Health Regulation, secondly, to demonstrate that China did not break these obligations based on the public records or disclosed evidences, and finally, to discuss the litigations in the United States against China from the perspectives of customary international law of the jurisdictional immunity of a state from another state. The method used by this paper is mainly normative analysis to interpret the relevant treaties and to review the cases of international and domestic courts in order to clarify what are the international obligations imposed on China in combating COVID-19 and what are the customary international laws related to the domestic jurisdiction on any cases against China. The conclusion of this paper is that China has not violated any international health laws and the customary international law of sovereignty immunity does not permit any domestic jurisdiction in this regard.
\end{abstract}

Keywords: COVID-19, Legal Issues, International Health Laws, Different Obligations, International Cooperation, State Immunity

\section{Introduction}

COVID-19 was first identified as the deadly novel coronavirus in China last January. Chinese government made great efforts to cooperated with the World Health Organization (WHO or Organization) for control of the coronavirus spreading over China and abroad, including the notification to WHO within 24 hours about the cases of pneumonia unknown etiology (unknown cause) detected in Wuhan City, ${ }^{1}$ the decision of lockdown measures in Wuhan City on 23 January 2020 to contain the spread of coronavirus and to stop Chinese transboundary travel during the traditional lunar new year. ${ }^{2}$ WHO has disclosed the report

1 The WHO official releases have the record that "on 31 December 2019, the WHO China Office was informed of cases of pneumonia unknown etiology (unknown cause) detected in Wuhan City, Hubei Province of China." See WHO: Novel Coronavirus (2019-nCoV), Situation Report-1, 21 January 2020.

2 The Chinese lunar new year began on 24 January 2020. It was the unprecedented of joint WHO-China study on the origins of COVID-19, which makes clear that "a laboratory origin of the pandemic was considered to be extremely unlikely", and provides the concluding remarks that "the team commended the engagement of all professionals who had spent long hours analysing very large quantities of data to support its work. In conclusion, the team called for a continued scientific and collaborative approach to be taken towards tracing the origins of COVIS-19." [1] The general background of the COVID-19 pandemic indicates that its origins remain unknown and the global cooperation is needed to continue scientific researches while combating the "enemy" to humankind with any possible effective and safe vaccines and

decision in the modern China's history to close any transportations in or out of Wuhan City with more than 12 million population and to prohibit Chinese travel abroad during national holiday. See the State Council Information Office of the People's Republic of China, June 2020, Fighting COVID-19 China in Action. Stage II: Initial Progress in Containing the Virus (January 20-February 20, 2020). 
medicines.

Even though the fighting COVID-19 is essentially a scientific issue, China has to face the legal challenges potentially before the International Court of Justice (ICJ) and actually in the federal courts of the United States. For examples, Mr. Peter Tzeng, an advocate, suggested to take China to the ICJ over COVID-19 by resorting Article 75 of the WHO Constitution and the jurisprudence of the ICJ. [2] Henry Jackson Society, the London based think tank, published a report on China's potential compensation of damages from the COVID-19 pandemic. [3] The filed cases in the United States claimed all direct and consequential damages [4] or economic and non-economic damages and losses caused by China. [6] But there are sound echoes in the academia of international law. Mr. David Filder believed that international health law would not provide any legal basis for such claims of damages from the COVID-19 pandemic. [7] It appears that legal research must be made to respond the accusations against China and to discuss the legal issues further from the standpoint of international law. The research is intended to make the preliminary arguments for merits with the clarification of relevant conventional or customary international laws in respects of state responsibility and state immunity related to the COVID-19 pandemic.

This paper will be focused on three critical issues, i.e., first, what are the legal obligations of international cooperation under the international health laws such as the WHO Constitution [8] and International Health Regulation (IHR or Regulation), [9] secondly, whether China violated these obligations, thirdly, whether the domestic courts of a state have jurisdiction over another state relating to the damages in the COVID-19 pandemic. Three issues are closely connected to the vital question: whether it is litigable against China over COVID-19 before the ICJ or any domestic courts of foreign countries.

\section{The Legal Obligations of International Cooperation Under International Health Laws}

It seems the common ground for the advised or the pending litigations to blame China's violation of the legal obligations of international cooperation under the international health laws. As mentioned above, someone suggested that it would be possible to take China to the ICJ under Article 75 of WHO Constitution involving the interpretation or application of Articles 6 and 7 of the IHR, which could be treated as the jurisdictional basis of the ICJ. [2] One of the lawsuits filed in the federal court of the United States also charged China with violation of the IHR for failing cooperation with WHO to notify information about COVID-19. [5] These accusations must be rejected by clarifying international health laws.

Basically, there are two different legal obligations of international cooperation in promoting the global health under international health laws. The first ones are the general obligations under the WHO Constitution for Member States to cooperate in good faith with each other and WHO, and the second ones are the obligations of implementation for Member States to collaborate actively with each other and WHO in accordance with the IHR.

The WHO Constitution provides that the Contracting Parties agree to the present Constitution for the purpose of cooperation among themselves and with others to promote and protect the health of all peoples. These obligations of cooperation include:

(1) To make the financial contributions to WHO (art.7). In account of the WHO functions (art.2) to act as the directing and coordinating authority on international health work, to establish and maintain effective collaboration with the United Nations (UN) and other appropriated organizations, and to assist the Members' government upon request, the Members' financial obligations are compulsory to carry out international cooperation for global health.

(2) To submit the reports to WHO, mainly, the annual regular reports "on action taken and progress achieved in improving the health of its peoples"(art.61), the annual reports of implementation "on the action taken with respect to recommendations made to it by the Organization and with respect to conventions, agreements and regulations" (art.62), the proper communications "to the Organization important laws, regulations, official reports and statistics pertaining to health which have been published in the States concerned" (art. 63), the statistical and epidemiological reports "in a manner to be determined by the Health Assembly" (art.64), and "the additional information pertaining to health as may be practicable." (art.65)

Under the WHO Constitution, the Member States shall comply with their obligations of report as described above, but no discipline to be taken by the Organization in the case of non-compliance. Even though WHO may take sanction on a Member for its failure to meet financial obligations to the Organization, it is not mandatory, because that "the Health Assembly may, or such condition as it thinks proper, suspend the voting privileges and services to which a Member is entitled." (art.7) Therefore, it is safe to say that the WHO Constitution imposes only general obligations on its Members, or in another words, that those obligations are pertained to the general subject matters of global health. So far it has virtually not occurred in the WHO history that "any questions or disputes concerning the interpretation or application of this Constitution" in respect of those general obligations were referred to the ICJ after failing to settle by negotiation or by the Health Assembly (art. 75). ${ }^{3}$

It is essentially different from the general obligations of international cooperation under the WHO Constitution, the

\footnotetext{
3 Only one case should be listed here in which Article 75 claimed as the treaty basis of the ICJ jurisdiction, but the complaint failed to show the dispute on interpretation or application of the WHO Constitution, and did not meet the preconditions of litigation before the ICJ even assuming the dispute as such. Case Concerning Armed Activities on the Territory of the Congo (New Application: 2002), (Democratic Republic of the Congo v. Rwanda), Jurisdiction and Admissibility, Judgment, ICJ Repots 2006, p. 43, paras. 99-100.
} 
WHO Member States have the particular obligations enforced by the IHR with the purpose "to prevent, protect against, control and provide a public health response to the international spread of disease in ways that are commensurate with and restricted to public risks, and which avoid unnecessary interference with international traffic and trade." (art. 2)

The WHO Member States as the IHR State Parties are obligated to "collaborate actively with each other and WHO, ... so as to ensure their effective implementation" (Preface) because of the international cooperation as the cornerstone of global health security for protection against the international spread of diseases. These obligations of implementation include:

(1) Surveillance. "Each State Party shall develop, strengthen and maintain, as soon as possible, ... the capacity to detect, assess, notify and report events in accordance with these Regulations, as specified in Annex 1." (art. 5.1)

(2) Notification. "Each State Party shall assess events occurring within its territory by using the decision instrument in Annex 2. Each State Party shall notify WHO, by the most efficient means of communication available, by way of the National IHR Focal Point, and within 24 hours of assessment of public health information, of all events which may constitute a public health emergency of international concern within its territory in accordance with the decision instrument, as well as any health measures implemented in response to those events." (art.6.1) "Following a notification, a State Party shall continue to communicate to WHO timely, accurate and sufficiently detailed public health information available to it on notified event" (art. 6.2).

(3) Information-sharing. "If a State Party has evidence of an unexpected or unusual public health event within its territory, irrespective of origin or source, which may constitute a public health emergency of international concern, it shall provide to WHO all relevant public health information." (art.7)

(4) Consultation. "In the case of events occurring within its territory not requiring notification as provide in Article 6, in particular those events for which there is insufficient information available to complete the decision instrument, a State Party may nevertheless keep WHO advised thereof through the National IHR Focal Point and consult with WHO on appropriate health measures." (art.8)

(5) Verification. If WHO believes that it is necessary to verify the information of domestic public health provided by a State Party, each State Party "shall verify and provide, within 24 hours, an initial reply, or acknowledgement of, the request from WHO”. (art.10. 1 and 2)

(6) Public health response. "When requested by WHO, State Parties should provide, to the extent possible, support to WHO-coordinated response activities." (art. 13.5)

In addition to those detailed obligations of international cooperation, the IHR also imposes the duties on the State Parties to response the specific potential public health risk at the points of entry, to take public health measures, to provide with health documents and to levy charges for health measures regarding travelers "in a transparent and non-discriminatory manners."(art. 42) It is permitted to extent additional two years only for any State Party to fulfil the obligation of surveillance capability-building.

It is obviously distinct that, on one hand, the general obligations under the WHO Constitution are regular for the Member States to make financial contribution, to submit the annual reports on domestic health situation, statistics and legislations, and on another hand, the obligations of implementation specified by the IHR are particularly related to any events that may constitute a public health emergency of international concern with mandatory surveillance, notification, information-sharing, consultation, verification and response. The two kinds of obligations are created by different treaties and pertained to different subject matters. Of cause, both have the common goals to promote and protect global health for all peoples.

Taking further account of the general international law of treaty, the WHO Constitution and the IHR are different multilateral treaties concluded in different times and with the manners for different objective or purpose by different subjects of international law, which determines the different obligations accordingly. The Constitution was concluded by 67 original contracting parties in 1946 for the objective to establish WHO in order to promote the highest possible level of health for all peoples, and the Regulation was adopted by the Health Assembly in 1969 and amended in 2005 with the purpose to prevent, protect against, control and provide a public health response to the international spread of disease. The two, therefore, are distinguished in aspects of general obligations from special obligations with the implementing functions. Although the Regulation is made in accordance with Articles 2 (k). 21 (a) and 22 of the Constitution, it would be confused to link directly the special obligations of the Regulation to the general obligations of the Constitution.

For an example, it is a misinterpretation that the special obligation to notify a particular event of public health emergency under Article 6 of the Regulation is derived from the general obligation to submit the regular reports in pursuing Article 61 of the Constitution, and the interpretation or application of Article 6 of the Regulation shall be treated accordingly as the interpretation or application of Article 61 of the Constitution, which arguably creates the conventional basis for the ICJ's jurisdiction, since a dispute only on interpretation or application of the Constitution could be brought to the ICJ in the case of failure to be settled by negotiation or by the Health Assembly. [2]

It must be clarified by the customary rules of treaty interpretation reflected in Article 31.1 of Vienna Convention on the Law of Treaty as the ICJ announced in the case Territorial Dispute [10] and subsequent cases. [11] Article 31.1 provides that "A treaty shall be interpreted in good faith in accordance with the ordinary meaning to be given to the term of the treaty in their context in the light of its object and purpose." Article 61 of the WHO Constitution provides that "Each Member shall report annually to the Organization on the action taken and progress achieved in improving the 
health of its peoples." The term "report annually" in its context of the chapter 14 "reports submitted by states" means that it is one of the annual reports to meet the WHO objective for "all people of the highest possible level of health". This obligation of annual report is different from the obligation of notification under the Article 6 of the IHR, which in its context of the part 2 "information and public health response" means that "all events which may constitute a public health emergency of international concern" within a Member's territory shall be notified to WHO as early as possible for the purpose "to prevent, protect against, control and provide health response to the international spread of disease". It must not be confused. This paper does not want to clarify all of misinterpretations by someone, but just to add one more example confusing the particular obligations of notification and information-sharing under Articles 6 and 7 of the IHR with the general obligation under Article 64 of the WHO Constitution to provide regular statistical and epidemiological reports simply for the disguised reason that both obligations are related to the "manner" to be determined by the Health Assembly, and then the disputes on interpretation or application of Articles 6 and 7 of the IHR could be treated as that of Article 64 of the WHO Constitution to provide the jurisdictional basis of the ICJ. [2] It is the same mistake to confuse the general obligation with special one because of ignoring the customary rule of treaty interpretation.

The clarification of different obligations might be helpful to understand the different procedures of dispute settlement by the Constitution and the Regulation. Article 75 of the Constitution provides that any question or dispute concerning the interpretation or application of this Constitution which is not settled by negotiation or by the Health Assembly shall be referred to the ICJ. In comparison, Article 56 of the Regulation directs the dispute parties first to negotiate or to seek any other peaceful means of their own choice including good office, mediation or conciliation, and secondly to get agreement referring the dispute to the WHO Director-General, who shall make every effort to settle it. Otherwise, "A State Party may at any time declare in writing to the Director-General that it accepts arbitration as compulsory with regard to all dispute concerning the interpretation or application of these Regulations to which it is a party or with regard to a specific dispute in relation to any other State Party accepting the same obligation." (art. 56.3) It shows the linkage between the treaty obligations and appropriate mechanisms of dispute settlement. The WHO Constitution provides the last resort to the ICJ because of disputes relating to the general obligations of international cooperation which may have the negative impacts on $\mathrm{WHO}$ as the UN specialized agency. The affordable procedure of dispute settlement under the Regulation is intended to resolve the problems or disputes arising from particular obligations to prevent international spread of disease by parties themselves or by the WHO Director-General, and even by the optional compulsory arbitration but not by adjudication of the ICJ. ${ }^{4}$ These conventional differences should not be confused by any international lawyers.

\section{China Did Not Violate the Obligations of International Cooperation}

The previous discussion paves the way to address the second legal issue: whether China did violate its obligations of international cooperation. In accordance with the general international law, any state shall be responsible for its international wrongful act when its conduct "consisting of an action or omission: (a) is attributable to the State under international law; and (b) constitutes a breach of an international obligation of the State". [12] It shall be ruled in accordance with the relevant international laws. [13] This paper is limited to the element (b) constituting the state responsibility regarding the general obligations under the WHO Constitution and the special obligations under the IHR respectively.

The WHO Constitution does not impose any disciplines on its Member States' non-compliance with the general obligations to submit annual reports. However, the principle of pacta sunt servanda is the general rule of international law, which requires that any contracting party of a treaty shall comply with the relevant obligations in good faith. ${ }^{5}$ China has good records of performance in this respect. China was the original WHO Member in 1946 and informed the WHO Director-General in August of 1972 for participant of its activities after the government of People's Republic of China was recognized by the UN General Assembly as the sole legitimate presentative of China in October of 1971. Since implementing the policy of reform and opening-up in 1979, China has been promoting the domestic system of public health and the international cooperation with WHO. In particular, China pledged the development, enhancement and maintenance of the core capability-building for rapid and effective response to public health hazards and public health emergency of international concern in accordance with the IHR. ${ }^{6}$ China has cooperated with WHO to make and enforce four Country Cooperation Strategic (CCS) since 2004. ${ }^{7}$ These official documents of cooperation cover all of information required by general obligations of annual reports under the WHO Constitution. The statistics data provided by China at the WHO Global Health Observatory is comprehensive ${ }^{8}$ China has fully carried out its obligations of

\footnotetext{
4 The ICJ lists the IHR (1969) as the treaty conferring jurisdiction on the Court, available at https://www.icj-cij.org/en/treaties, visited on 20 June 2020. The article 93.3 of the IHR (1969) confers jurisdiction on the ICJ, but it has already been replaced by the IHR (2005) without such identified article.

5 See Vienna Convention on Law of Treaty, article 26.

6 See China's declaration. 2005, in the International Health Regulation (2005), third edition, p. 62.

7 See China-WHOCCS (2004-2008), China-WHOCCS (2008-2013), China-WHOCCS (2013-2015) and China-WHOCCS (2016-2020).

8 See China statistics summary (2002-present), WHO website, available at https://apps.who.int/gho/data/node.country.country-CHN?lang=en.visited on 20
} 
international cooperation for global health, and did not conduct any wrongful international act constituting a breach of international obligation under the WHO Constitution.

The IHR imposes special obligations on its State Parties to implement the international cooperation. Some American politicians and the medias accused China's initial cover-up and delayed release of information resulted in the spread of the virus over the world. ${ }^{9}$ Did China violate its obligations of international cooperation under the IHR, in particular, Article 6 and Article 7 of the IHR?

It would be summarized of the previously described obligations of notification under Article 6 of the IHR, i.e., for a State Party, first, to make an assessment on any event of potential international public concern including those of unknown causes or sources in its territory according to the definition and procedure of decision instrument, as well as any health measures in response to those events; secondly, to notify WHO by its competent authority within 24 hours; thirdly, to continually communicate to WHO timely any information relevant to the notified events and the measures of response.

The evidences of China's performance of fighting COVID-19 have been disclosed publicly. On 27 December, the local hospital in Wuhan City reported cases of pneumonia of unknown cause to the Wuhan Jianghan Center for Disease Prevention and Control; upon receiving the relevant information, on 30 December, the National Health Commission (NHC) acted immediately to organize research into the disease and send a working group and an expert team to Wuhan on 31 December and same day, Wuhan City Health Commission released publicly the 27 confirmed cases; on 1 January 2020, the NHC received the first batch of samples of four cases discovered in Wuhan and began the pathogen identification process; on 3 January, the NHC officially notified WHO about disease of unknown causes while formulating documents for local hospitals' diagnosis and treatment. ${ }^{10}$ The WHO official releases, in fact, have the record that "on 31 December 2019, the WHO China Office was informed of cases of pneumonia unknown etiology (unknown cause) detected in Wuhan City, Hubei Province of China." "In checking the requirements of the IHR regarding process of assessment and timely notification, it is satisfied that upon receiving the information about pneumonia of unknow causes on 30 December 2019, the NHC notified the WHO China Office within 24 hours, and after making the preliminary assessment of "Viral Pneumonia of Unknown Cause" through laboratory testing of the samples to identify the pathogen on 3 January 2020, China immediately notified

June, 2020.

9 See China Ministry of Foreign Affairs, 2020, Reality Check of US Allegation Against China on COVID-19. MFA website, available at

https://www.fmprc.gov.cn/mfa_eng/topics_665678/kjgzbdfyyq/t1777545.shtml, visited on 20 June, 2020

10 See the State Council Information Office of the People's Republic of China, June 2020, Fighting COVID-19 China in Action. Stage I: Swift Response to the Public Health Emergency (December 27, 2019-January 20, 2020).

11 WHO: Novel Coronavirus (2019-nCoV), Situation Report-1, 21 January 2020.
WHO. It is no doubt that China did not violate the obligation under Article 6.1 of the IHR.

On 7 January 2020, the Chinese Center for Disease Control and Prevention succeeded in isolating the first novel coronavirus strain; on 8 January, an expert evaluation team designated by the NHC initially identified a new coronavirus as the cause of the disease; on 9 January, and China also immediately notify WHO of these information; on 10 January, China came up with an initial version of test kits and immediately began to test all relevant cases admitted to local hospitals to screen for the new coronavirus; on 11 January, China started to update WHO on a daily basis. ${ }^{12}$ These facts are confirmed by the WHO situation report: "the Chinese authority identified a new type of coronavirus, which was isolated on 7 January 2020. On 12 January 2020, China shared the genetic sequence of the novel coronavirus for countries to use the development specific diagnostic kits."13

China also fully obeyed its obligation under Article 6.2 of the IHR to continue to communicate to WHO timely, accurate and sufficient detailed public health information available to it on the notified event and measures of response. No violation was found.

Article 7 of the IHR requires that "If a State Party has evidence of an unexpected or unusual public health event within its territory, irrespective of origin or source, which may constitute a public health emergency of international concern, it shall provide to WHO all relevant public information. In such a case, the provisions of Article 6 apply in full." This obligation of information-sharing means that no matter what is the origin or source of the event which may constitute a public health emergency of international concern, a State Party shall provide any relevant information to WHO. So far, the origin or source of COVID-19 has not been identified. [1] China stands in "supporting global research by scientists on the source and transmission routes of the virus." Upon confirming the early cases of a pneumonia of unknown cause, China notified WHO timely and continued to provide WHO with all of the relevant information. No state responsibility shall be reserved to China due to any breach of obligation under Article 7 of the IHR.

In a word, China did nothing wrong in actions or omissions which may constitute a breach of either general obligations under the Constitution or in particular during the COVID-19 epidemic, implementing obligations under the Regulation. It should be emphasized that the 73 World Health Assembly adopted the resolution which requests the WHO Director-General to "initiate, at the earliest appropriate moment, and in consultation with Member States, a stepwise process of impartial, independent and comprehensive evaluation," 15 including the functioning of the IHR in each

12 See Fighting COVID-19 China in Action. Stage I.

13 Novel Coronavirus (2019-nCoV), Situation Report-1.

14 Jinping, Xi, 18 May 2020, Statement at the Virtual Event of the Opening of the 73rd World Health Assembly, MFA website, available at, https://www.fmprc.gov.cn/mfa_eng/topics_665678/kjgzbdfyyq/t1780682.shtm, visited on 22 June, 2020

15 WHO, 18 May 2020, COVID-19 response, A73/CONF./1, OP9.10. 
Member State to implement its relevant obligations. It is expected to have an objective evaluation for Member States' performances in response to the COVID-19 pandemic.

\section{No Jurisdiction of Domestic Court over Foreign Countries on Cases of the COVID-19 Pandemic}

As mentioned, some cases have been filed in the federal courts of the United States against China for misdealing the COVID-19 pandemic. It is not only contrary to the demonstrated facts disclosed already by the WHO official releases, but also absolutely violates the customary international law of state immunity if these domestic courts declare their jurisdictions over China. That is the third issue for further discussion. The focus is different from the above issues but linked because of no ground to accuse China before the ICJ and any domestic courts of foreign countries if the previous clarifications of international health laws could not be rebuttal. The difference is that the ICJ jurisdiction is conventional basis for inter-states disputes while being solely contingent on customary international laws for a state to immunize from another state's jurisdiction.

Hugo Grotius, the founder of modern international law, pointed out that "Truly, there is no greater sovereign power set over the power of the state and superior to it, since the state is a self-sufficient aggregation. Nor was it possible for all of the nations not involved in a dispute to reach an agreement providing for an inquiry by them into the case of each disputant." 16 It was perhaps the first statement on the principle of state immunity, i.e., "the rule par in parem non habet imperium - no state can claim jurisdiction over another," [14] which became a general rule of customary international law since then. The Permanent Court of International Justice in 1927 delivered its opinion on "Lotus case": "Now the first and foremost restriction imposed by international law upon a State is that - failing the existence of a permissive rule to the contrary - it may not exercise its power in any form in the territory of another State. In this sense jurisdiction is certainly territorial; it cannot be exercised by a State outside its territory except by virtue of a permissive rule derived from international custom or from a convention." [15] Professor Louis Henkin, the chief editor of Restatement (third) of Foreign Relation Law of the United States, also believed that "the immunity of states from adjudication and enforcement remained a staple of customary international law. State favored it: they enjoy its benefits and were not hampered by it since states did not commonly seek to sue other states in municipal courts."[16] The rule of a state of immunity from jurisdiction of another state has been established as the customary international law, which is confirmed by the UN Convention on Jurisdictional

16 Grotius, Hugo, Commentary on the Law of Prize and Booty, translated by Gwladys L. Williams, Oxford: at the Clarendon Press, 1950, p. 28. This book was written in 1604, but published in 1865 and English version in 1950.
Immunities of States and Their Property (Convention) in the opening words that "the jurisdictional immunities of States and their property are generally accepted as a principle of customary international law". 17 In considering this convention not yet in force, the ICJ, in a case on jurisdictional Immunities of the States, made it clear that as between the parties of the dispute "any entitlement to immunity can be derived only from customary international law, rather than treaty." [17] This case was arisen from the domestic courts in Italy and Greece rulings against Germany. Germany claimed that those rulings violated the customary international laws of state immunity. In the ICJ opinion, the general practice of states "shows that, whether in claiming immunity for themselves or according it to others, States generally proceed on the basis that there is a right to immunity under international law, together with a corresponding obligation on the part of other States to respect and give effect to that immunity." [18] This is the customary international law on state immunity with the universal binding force on any states in the world.

It is the cornerstone of international community to govern the relationship between or among the sovereign states that a state has no jurisdiction over another state on any state acts conducted in its territory. It is prohibited to sue against China in any American courts under customary international law of state immunity. Whatever China has done in its territory to fight COVID-19 is within its sovereign scope as the state acts. No state has jurisdiction over China to make any judgment accordingly. The domestic jurisdiction is fundamentally different from the jurisdiction of international adjudication. As discussed already, Article 75 of the WHO Constitution and Article 57 of the IHR provide the jurisdictions separately for the ICJ or the optional compulsory arbitration on the disputes about interpretation or application of the respective treaties in the case of preconditions satisfied. The jurisdiction of international adjudication depends on the common consent of dispute parties who set mandatory preconditions to be met, which, in sense, means that the parties may give up their sovereign rights conditionally to accept the jurisdiction of international adjudication. Similarly, a state may agree to accept other states' jurisdiction. The UN Convention provides with exceptions of jurisdictional immunity of states on their acts relating to the commercial transaction, the contracts of employment, the personal injuries and damage to property, the ownership, possession and use of property, the intellectual and industrial property, the participation in companies or other collective bodies, the ships owned or operated by a state, the effect of an arbitration agreement. ${ }^{18}$ These are the relative jurisdictional immunities of state based on a convention but not customary international law. However, the UN Convention has not been in force yet, which clearly designates that international community has

17 United Nations Convention on Jurisdictional Immunities of States and Their Property, 2004, not yet in force.

18 See United Nations Convention on Jurisdictional Immunities of States and Their Property, Part III, Proceeding in which State Immunity cannot be invoked. 
not been ready to accept the relative state immunity as well as the conditions to determine particular exception of state immunity. In another word, until now there is no legal basis of either conventional law or customary international law about these relative jurisdictional immunities of state. In contrast, "the immunity of State and its property from the jurisdiction of the courts of another State"19 is still absolute but not relative under the existing customary international law.

The jurisdiction of litigations against China in the federal courts of the United States is exclusively based on its domestic law, the Foreign Sovereign Immunities Act (FSIA) of $1976 .^{20}$ The $\S 1605$ of FSIA provides that "(a) A foreign state shall not be immune from the jurisdiction of courts of the United States or of the States in any case -... (2) in which the action is based upon a commercial activities carried on in the United States by the foreign state; or upon an act performed in the United States in connection with a commercial activity of the foreign state elsewhere; or upon an act outside the territory of the United States in connection with a commercial activities of the foreign state elsewhere and that act causes a direct effect in the United States." It also provides that "(a) A foreign state shall not be immune from the jurisdiction of courts of the United States or of the States in any case...$-(5) \ldots$ in which money damages are sought to or loss of property, occurring in the United States and caused by the tortious act or omission of that foreign state or of any official or employee of that foreign state while acting within the scope of his office or employment". The allegations in these cases misrepresent the facts that China waged an all-out people's war fighting COVID-19 and put the life and health of Chinese people as priority to treat each patient with any costs whatever had been taken by government. ${ }^{21}$ What did China do as "the commercial activities"? What did China do as "the tortious act or omission"? The accusations are undeniably misleading.

It is more important to pay attention that the American government likely encourages the litigators to seek damages from China based on its domestic law prevailing over the customary international law instead of concentrating itself on its own obligations to fight COVID-19 while even not signing the UN Convention yet.

What is customary international law? It is unwritten law deriving from general practice of states accepted as law. "It remains an import source of public international law" according to the UN International Law Commission's commentary. [19] Actually, it was the wordings used by the

19 United Nations Convention on Jurisdictional Immunities of States and Their Property, Article 1.

20 Foreign Sovereign Immunities Act of 1976, 28 U.S.C. Sec. 1605. For an example, see Case: 1: 20-cv-00090 Doc.\#: 1 Filed: 04/21/20, paras. 38, 41.

21 China provides free treatment for patients. As of 31 May 2020, the medical bills of 58,000 inpatients with confirmed infections had been settled by basic medical insurance, with a total expenditure of RMB1.35 billion, or RMB23,000 per person. The average cost for treating the Covid-19 patients in severe condition surpassed RMB150,000, and in some critical cases the individual cost exceeded RMB1 million, all covered by the state. See Fighting COVID-19 China in Action. II. 3.
Supreme Court of the United States. Going back in earlier 1800 s, the Court recognized customary international law being applicable in the United States even no expressed statement in its Constitution as such, since "the Court is bound by the law of nations which is part of law of the land."[20] Subsequently, the Court repeated again that "the international law is part of our law and must be ascertained and administered by the court of justice of appropriate jurisdiction, as often as questions of right depending upon it are duly presented for their determination."[21] It was confirmed by the case "Paquete Habana". [22] It is still debated on the issue of customary international law as a part of American laws, ${ }^{22}$ but these case laws continue being applicable as the Restatement (third) elucidated that "customary law that has been developed since the United States became a state is incorporated into United States law as the time it matures into international law." [24]

Why does the promulgation of FSIA and its application shift to the contrary to customary international law of state immunity? It might be understandable to begin with the Tate's letter in 1952 which pronounced to abandon the absolute theory of sovereign immunity and to embrace the restrictive view under which immunity in the courts of the United States should be granted only with respect to causes of action arising out of a foreign state's public or governmental actions and not with respect to those arising out of its commercial or proprietary actions. ${ }^{23}$

But in 1964, the Supreme Court of the United States nevertheless applied the act of state doctrine for the case relating to Cuba's nationalization of American companies' assets in its territory, insisting in its preferred doctrine: "Every sovereign state is bound to respect the independence of every other sovereign state, and the courts of one country will not sit in judgment on the acts of government of another, done within its own territory."[25] This doctrine was established by the case laws. [26] The Court hesitated to make ruling on a commercial transaction conducted by Cuba's national bank using the nationalized American companies' assets for business, and let the federal executive branch of foreign affairs to handle it. It is true that this doctrine was originated from American case laws,[27] but the Court believed that "The traditional view of international law is that it establishes substantive principles for determining whether one country has wronged another. Because of its peculiar nation-to-nation character the usual method for an individual to seek relief is to exhaust local remedies and then repair to the executive authorities of his own state to persuade them to champion his claim in diplomacy or before an international tribunal."'[23] This doctrine is substantially identified with the rule of a state immunity from jurisdiction of another state. It incorporates the customary international law of state immunity into the case laws of judicial restriction,

22 See the Symposium on Foreign Affairs Law at the End of Century, 1999, 70 U. Colo. L. Rev. 1089-1594.

23 See Letter of Acting Legal Advisor, Jack B. Tate, to Department of Justice, 19 May 1952, 26 Department of State Bulletin (1952), p. 984. 
but in effect excludes jurisdiction of domestic courts of a state over the acts of another state in its territory.

Concerning the acts of state doctrine to block the American owners' claims in domestic courts for compensation of the Cuba's nationalization of their assets, the Congress of the United States adopted the Second Hickenlooper Amendment in 1964, which provides that "no court in the United States shall decline on the ground of the federal act of state doctrine to make a determination on the merit giving effect to the principle of international law in a case in which a claim of title or other right to property is asserted by any party including a foreign state (or a party claiming through such state) based upon (or traced through) a confiscation or other taking after January 1959, by an act of that state in violation of the principles of international law including the principles of compensation and the other standards set out in this subsection". ${ }^{24}$ Subsequently, the Supreme Court of the United States made its decisions following the Tate's Letter to restrict the jurisdictional immunity of foreign states on their commercial acts. In 1976, the Court delivered the opinion in a landmark case that "we are nevertheless persuaded by the arguments of petitioner and by those of the United States that the concept of an act of state should not be extended to include the repudiation of a purely commercial obligation owed by a foreign sovereign or by one its commercial instrumentalities." [28] The conclusion of the majority was that "the restrictive approach sovereign immunity suggests that these established rules should be applied to the commercial transactions of sovereign states. Of cause, sovereign immunity has not been pleaded in this case; but it is beyond cavil that part of the foreign relation law recognized by the United States is that the commercial obligations of a foreign government may be adjudicated in those courts otherwise having jurisdiction to enter such judgments."[29] This case law illustrates the legal connect between the act of state doctrine and the state immunity that upon finding the purely commercial obligation of an act of state, any American court shall not grant immunity to a foreign state. In separating a purely commercial act from traditional public acts of state, American courts apparently continue to follow customary international law of state immunity. These practices were codified as the statute of FSIA in 1976 with the exceptions of commercial transaction and more. Nowadays, the Restatement (fourth) of Foreign Relation Law of the United States explains that "foreign states are presumptively immune from jurisdiction in federal and State courts unless one of its exceptions applies.'[30] The FSIA and its application appears to masquerade the compliance with customary international law for the reason of distinguishing the purely commercial acts from traditional public acts of foreign states, but actually deviates from the existing customary international law of state immunity which remains unchanged as the ICJ confirmed in the case "Jurisdictional

24 The Second Hickenlooper Amendment, Pub. L. 89-171, 79 Stat. 653 (1964), 22 U.S.C. Sec. 2370 (e) (2).
Immunities of the State" that "whether in claiming immunity for themselves or according it to others, States generally proceed on the basis that there is a right to immunity under international law, together with a corresponding obligation on the part of other States to respect and give effect to that immunity." [17]. Thus, any litigations against China in any American courts must be condemned as the violation of customary international law.

In summary, the FSIA is codification of American case laws, which seems to respect only the public acts of foreign states. However, the exceptions of state immunity have not been universally accepted as the customary international law. In contrast, as required the existing customary international law, the courts of a state have no jurisdiction over another state on any acts of state in its own territory. It is still absolutive not relative. Therefore, the United States put its domestic law prevailing over the customary international law of state immunity, which may constitute an international wrongful act as such.

\section{Conclusion}

The fighting COVID-19 needs international cooperation of each and every state in the world. The international health laws require general and special obligations of international cooperation for global health. But it shall not confuse the general obligations to regularly make financial contribution, to submit annual reports of different subject matters to WHO under its Constitution with the special obligations to implement some emergent duties to notify WHO any events possibly constituting public health emergency of international concern and necessary information in detail timely to prevent international spread of diseases under the IHR. The dispute settlement mechanisms are also different respectively. These conventional differences shall be distinguished. China has made great efforts to ensure the conformity with the general obligations under the WHO Constitution, and in particular, complied with the special obligations under the IHR in fighting COVID-19. It could not be found anything about Chinese breaches of international health laws. There are no factual and legal basis of any allegations against China possibly in the ICJ or any domestic courts of another country. Any litigations taken in the United States to claim damages from China absolutely violate customary international law of state immunity.

\section{References}

[1] WHO-convened Global Study of Origins of SARS-CoV-2: China Part, Joint WHO-China Study, 14 January-10 February 2021, Joint Report, p. 120.

[2] Peter Tzeng, "Taking China to the International Court of Justice over COVID-19”, EJIL: Talk, Blog of the European Journal of International Law, April 2, 2020; available at http://ejiltalk.org/taking-china-to-the-international-court-of-jus tice-over-covid-19, visited on 1 May 2021. 
[3] Henderson, Matthew and Mendoza, Alan etc. "Coronavirus Compensations? Assessing China's Potential Culpability and Avenues of Legal Response", Henry Jackson Society. April 2020, available at https://henryjackson society.org/publications/coronaviruscompesation/, visited on 1 May 2021.

[4] The State of Missouri v. China, Case: 1: 20-cv-00090 Doc.\#: 1 Filed: 04/21/20, p. 46.

[5] The State of Missouri v. China, Case: 1: 20-cv-00090 Doc.\#: 1 Filed: 04/21/20, para. 143 .

[6] Azalea Woods of Ouachita etc., v. China, Case 3: 20-cv-00457-TAD-KLH Doc.\#1 04/13/2020, p. 13.

[7] David Fidler, "COVID-19 and International Law: Must China Compensate Countries for the Damages?" Just Security March 27, 2020, available at https://www.just security.org/69394/covid-19-and-international-law-must-china -compensate-countries-for-the-damage-international-health-re gulations/ visited on 1 May 2021.

[8] The Constitution of the World Health Organization, 14. U. N. T. S. 185.

[9] WHO, the International Health Regulation (2005) third edition, 2016.

[10] Territorial Dispute (Libyan / Chad), Judgment, ICJ Reports 1994, pp. 20-21, para. 41.

[11] Guenther Dahlhoff, International Court of Justice, Digest of Judgment and Advisory Opinions, Cannon and Case Law, 1946-2012, Leiden: Martinus Nijhoff Publishers, 2012, pp. 1784-1789.

[12] ILC, Responsibility of States for International Wrongful Acts, 2001, YILC, 2001, vol. II (Part Two), article 2.

[13] James Crawford, Alain Pellet, and Simon Olleson, The Law of International Responsibility, Oxford: Oxford University Press, 2010, pp. 397-403.

[14] Robert Jennings and Arthur Watts, Oppenheim's International Law, 9th edition, Vol. 1 London: Longman Group UK Limited, 1993, p. 341.
[15] The Case of the S. S. "Lotus", PCIJ, Series A-No. 10, September 7th, 1927, pp. 18-19.

[16] Henkin, Louis, International Law: Politics and Values, Leiden: Martinus Nijhoff Publishers, 1995, p. 266.

[17] Jurisdictional Immunities of the State (Germany v. Italy; Greece Intervening), Judgment, ICJ Reports 2012, p. 122, para. 54.

[18] Jurisdictional Immunities of the State, ICJ Reports 2012, p. 123, para. 56.

[19] Draft conclusions on identification of customary international law, with commentaries, 2018, YILC, vol. II, Part Two, p. 2.

[20] The Nereide, 13 U.S. (9 Cranch) 388 (1815), at 423.

[21] Hilton v. Guyot, 159 U.S. 113 (1895), at 163.

[22] The Paquete Habana, 175 U.S. 677 (1900), at 700.

[23] Banco Nacional de Cuba v. Sabbatino, at 423.

[24] Restatement (Third), Foreign Relations Law of the United States, the American Law Institute, 1987, Part I, Chapter 2, Introductory Note.

[25] Banco Nacional de Cuba v. Sabbatino, 376 U.S. 398, at 416.

[26] Underhill v. Hernandez, 168 U.S. 250 (1897), at 252.

[27] Philippa Webb, International Law and Restraints on the Exercise of Jurisdiction by National Courts of States, in International Law, fifth edition, edited by Malcolm D. Evans, Oxford: Oxford University Press. 2018, p. 317.

[28] Alfred Dunhill of London Inc. v. Republic of Cuba, 425 U.S. 682, at 695.

[29] Alfred Dunhill of London Inc. v. Republic of Cuba, at 704-705.

[30] Restatement (Fourth), Foreign Relations Law of the United States, the American Law Institute, 2018, Chapter 5. Introductory Note. 